\title{
CORVITIN MODULATES THE CONTENT OF LIPIDS IN RAT LIVER BILE
}

\author{
T. V. VOVKUN ${ }^{1}$, P. I. YANCHUK ${ }^{1}$, L. Ya. SHTANOVA ${ }^{1}$, \\ S. P. VESELSKY ${ }^{1}$, N. B. FILIMONOVA ${ }^{1}$, I. V. KOMAROV ${ }^{2}$ \\ ${ }^{1}$ ESC "Institute of Biology and Medicine”, National Taras Shevchenko University of Kyiv, Ukraine \\ 2 "Institute of High Technologies", National Taras Shevchenko University of Kyiv, Ukraine; \\ e-mail:shtanova@ukr.net
}

Received: 23 March 2019; Accepted: 18 October 2019

\begin{abstract}
Quercetin (QUE) and its water-soluble form corvitin are medicinally important members of the flavonoid family and the most prominent dietary antioxidants. Numerous pharmacological effects of quercetin include protection against diseases, such as atherosclerosis, myocardial infarction, and cerebrovascular diseases. Corvitin modulates liver blood flow but its effects on liver lipid metabolism have not been understood. We investigated the influence of corvitin $(2.5,5,10 \mathrm{mg} / \mathrm{kg})$ on the formation and secretion of cholesterol (Chol), cholesterol esters (EChol), phospholipids (PLS), free fatty acids (FFAs), and triglycerides (TGs) into the bile. Secreted bile was collected during $2.5 \mathrm{~h}$ of the experiment. Lipid fractions of the bile were separated by thin-layer chromatography. We defined that administration of corvitin caused a significant $(P<0.05-$ 0.001) increase in levels of all studied lipid components of bile. At a dose of 2.5 and $5 \mathrm{mg} / \mathrm{kg}$ corvitin increased bile content of Chol, PLs and FFAs, and at a dose of $10 \mathrm{mg} / \mathrm{kg}$ had the largest effect on the total production of EChol and TGs. We concluded that corvitin activates the liver lipids metabolism and processes of bile formation.
\end{abstract}

Ke y wo rds: corvitin, liver, bile, cholesterol, cholesterol esters, phospholipids, free fatty acids, triglycerides.

$\mathrm{B}$ ile formation is a unique function of the liver, which is vital to the survival of the organism. The bile is a complex aqueous product, which contains bile acids (BAs) and numerous lipid components, including, phospholipids (PLs), free cholesterol (Chol), cholesterol esters (EChols), and to a lesser extent free fatty acids (FFAs) and triglycerides (TGs). The liver actively eliminates Chol by secreting of it into the bile either directly or after its conversion into BAs, thereby regulating its levels in the body. Therefore, Chol balance is achieved by modulating its esterification, biosynthesis, and excretion [1]. The liver is the central organ involved in the metabolism of lipids, which are the key source of energy in the body and might cause various pathological conditions. In particular, the accumulation of lipids in hepatocytes results in disorders of lipid metabolism and may be a stimulus to many chronic metabolic diseases, especially fatty liver degeneration, which leads to hepatic cirrhosis, hepatic failure, and hepatocellular carcinoma, in the absence of alcohol abuse [2]. Hepatoprotective drugs applied in clinical practice often have undesirable side effects, especially if they are used chronically or subchronically. Based on this, there has been interest of scientists and clinicians in finding various natural compounds with hepatoprotective properties that would be combined with a lack of toxicity, harmful side effects on the body and low cost.

Hyperlipidemia is one of the major risk factors for heart diseases, including atherosclerosis, myocardial infarction, and cerebrovascular diseases [3]. Nowadays, in developing countries, hyperlipidemia and atherosclerosis are among the major causes of cardiac illness and death. Cardiovascular diseases are a major cause of disability and mortality worldwide. According to the World Health Organization, 17 million people die every year from myocardial infarction and other cardiovascular diseases [4]. Annually, in Ukraine, about 50000 people are esti- 
mated to have acute myocardial infarction. Mortality statistics from this illness in Ukraine remains steadily high $-30 \%$ of patients die from acute myocardial infarction, while in the Western countries - only 5\% [5].

Most of the hypolipidemic herbal medicines that used worldwide have excellent pharmacological properties without side effects. Natural products are often attractive in medicinal chemistry because of their safety. In the last decade, many studies have focused on a variety of natural products used for the prevention and treatment of lipid metabolism disorders. In these studies, phenolic compounds such as flavonoids have attracted great interest, having pharmacological properties involved in efficient regulation of plasma lipids [6]. Flavonoids are a large group of naturally occurring compounds that are found in plants and are frequently consumed as part of the human diet. They are receiving much attention nowadays for their potential pharmacological properties, low toxicity, expressed antioxidant, anti-inflammatory and other properties beneficial for human health [7].

Quercetin (QUE) (3,3',4',5,7-pentahydroxyflavone), a common member of the flavonoid family, is present widely in vegetables, fruits, tea, and red wine. This flavonoid acts as a scavenger of superoxide and hydroxyl radicals or an inhibitor of lipid peroxidation and also possesses anti-inflammatory, vasodilator effects, anti- hypercholesterolemic and antiatherosclerotic activities [8]. Recently, the findings of Son $\mathrm{HY}$ et al. demonstrated that QUE is effective in regulating Chol metabolism [9]. This substance has been characterized in several studies as a flavonol with a potent hepatoprotective and antifibrotic properties which increases antioxidant capacity and improves the functional status of the liver tissue affected by various harmful factors $[10,11]$. Little information is available regarding the influence of QUE on bile lipids. The study of the QUE effects in vivo is complicated by the low bioavailability of this compound.

Corvitin is a water-soluble analogue of QUE with a similar biological and therapeutic activity. Unlike the QUE, corvitin dissolves readily in water and saline inducing a rapid response from the test organs after administration. In Ukraine, corvitin is used in clinical cardiology as a blocker of 5-lipoxygenase activity in the treatment of coronary heart disease and myocardial infarction [12]. In our previous studies, we found that this drug increased tis- sue blood flow in the gastric mucosa and liver [13]. In other studies, we observed the accelerated recovery of tissue blood flow in the pancreas, gastric mucosa and liver of rats with acute pancreatitis following the treatment with corvitin [14]. In addition, recently, we have found that corvitin increased biliary content of both free and conjugated with amino acids BAs in rats depending on the tested doses [15]. The impact of corvitin on the hepatic formation and excretion of lipids in bile has not been investigated yet. The scheme of the experiment allowed us to estimate the effect of the test factors in dynamics. In this way, we could determine the latency of corvitin-induced impact on the examined parameters and time intervals when the drug had the greatest effect on certain parameters of the lipid bile composition.

\section{Materials and Methods}

This study was conducted according to the decision held by Biological Ethics Committee, Faculty of Biology, National Taras Schevchenko University of Kyiv (protocol No 3 from April 9, 2009). This work has been done in accordance with European Convention for the protection of vertebrate animals used for experimental and other scientific purposes (Strasbourg, 1986), as well as "Bioethical expertise of preclinical and other scientific researches conducted on animals" (Kyiv, 2006). Before starting the experiments, twenty six 12-week-old mature male Wistar rats, weighing 220-250 g were housed in a controlled environment $\left(22 \pm 2^{\circ} \mathrm{C}\right.$, a relative humidity of 45-55\%, 12 h light/dark cycle), 6 animals per cage, with free access to food and tap water during the acclimatization period. Acute experiments were conducted after $18 \mathrm{~h}$ of fasting. Rats were randomly divided into 4 groups of 6 animals each. The rats were anesthetized with natrium thiopentalum (Kyivmedpreparat, Ukraine, 4 mg/100 g, i.p.). Control animals (group I) were injected intraportally with a bolus of vehicle (sodium chloride $0.9 \%$, $0.1 \mathrm{ml} / 100 \mathrm{~g}$ ), whereas rats from model groups: II, III, and IV received corvitin $2.5,5$ and $10 \mathrm{mg} / \mathrm{kg}$, respectively, [13] in the same manner. Corvitin was supplied by the PJSC SIC Borshchahivskiy CPP (Kyiv, Ukraine). The purity of test samples was more than 99\%. Anesthetized rats were subjected to laparotomy, and the common bile duct was cannulated with a polyethylene catheter. All administrations were performed after an equilibration period of $30 \mathrm{~min}$ to stabilize the bile flow rate. Secreted bile was collected every 30 min in the course of 2.5-hour 
experiment by micropipette connected to a cannula, located in the bile duct. Bile lipids were separated by the method of thin-layer chromatography [16]. For this purpose, $0.1 \mathrm{ml}$ of bile was added to $2.4 \mu \mathrm{lmix}$ ture of chloroform-methanol $(2: 1)$, and $0.5 \mathrm{ml}$ acidified water $(0.5 \mathrm{ml}$ of concentrated sulfuric acid per 1 liter of double-distilled water) was added in $5 \mathrm{~min}$. Samples were kept overnight for complete separation into two phases. The lower phase contained lipids. The extract was dried at $70^{\circ} \mathrm{C}$. The dry residue was dissolved in $40 \mu \mathrm{l}$ of chloroform-methanol mixture ( $3: 1)$ and put on the plate as a thin strip. Chromatography was performed in a chamber, saturated by solvent vapor. The system of eluents included petroleum ether, diethyl ether, ether, glacial acetic acid (30: $10: 0.2$ ). Fractions of biliary lipids were stained with 5\% phosphomolybdic acid in 96\% ethanol, followed by heating at $100{ }^{\circ} \mathrm{C}$ for $5 \mathrm{~min}$. Identification of the major lipid fractions was performed using standards and color of the spots, considering the relative mobility of fractions.

For quantitative evaluation of individual fractions of lipids in bile, solutions of their main components (1 mg of substance per $1 \mathrm{ml}$ of solvent), both individually and in a mixture with specimens of other fractions, were prepared. This mixture of standards is quantitatively (from $1 \mu 1$ to $2 ; 5 ; 10 ; 15 ; 20 ; 25$ and $30 \mu \mathrm{l})$ adsorbed on chromatographic paper. After extraction and concentration of bile at the bottom of the cone tube, it should be dissolved in $50 \mu \mathrm{l}$ of solvent and dropped a few times with a micropipette $(5 \mu \mathrm{l})$ on the surface of a prepared and marked chromatographic plate. Chromatographic separation of lipid components of bile was carried out on Silufol plates. After developing with an aqueous phosphomolybdic acid solution, quantitative estimation of color intensity of each fraction was carried out with the use of densitometer DO-1M. The area of the spot was also measured. The value of the combined test is shown on the $\mathrm{y}$ axis of the calibration graph, and the $\mathrm{x}$-axis is marked with the known amount of a corresponding standard - a witness of the presence of this lipid fraction. These parameters were evaluated for fractions of lipids from samples of the investigated bile. Based on the calibration curve, the amount of the corresponding lipid was determined in $\mu \mathrm{g}$. Finally, taking into account the dilution and the part of the extract, we determined the amount of lipids in mg per $100 \mathrm{ml}$ of bile.

The results were processed by one-way analysis of variance (ANOVA) followed by Newman-Keuls post hoc test. They were presented as mean \pm the standard error of the mean \pm SEM and considered statistically significant at $P<0.05$. Observed power $($ alpha $=0.05)$ was 0.9. The most pronounced effect of corvitin was expressed as partial eta-squared $\left(\mathrm{y}_{\mathrm{p}}{ }^{2}\right)$, the value of which was defined as the proportion of the effect + error variance that is attributable to the effect.

\section{Results and Discussion}

To investigate the effect of corvitin on lipid excretion, we treated laboratory rats with this drug and determined the changes in the content of lipids in the bile at each time point throughout the measurement period. It has been demonstrated that corvitin significantly promoted excretion of lipids from the liver into the bile. Hepatocytes directly uptake lipids from the blood with the help of microvilli. In the liver, the following processes of lipid metabolism take place: oxidation of TGs, formation of acetone bodies, synthesis of TGs, PLs, lipoproteins, EChols and free Chol. The liver plays a central role in the regulation of Chol homeostasis. Chol enters the organ in the form of chylomicrons and low-density lipoproteins or is synthesized de novo from acetyl coenzyme A via a cascade of enzymatic reactions in which 3-hydroxy-3 methyl glutaryl CoA reductase (HMG-CoA) is a key enzyme [17]. Chol is present in the liver in free form and the form of EChols. There are two effective ways to remove Chol from the body: the degradation of the compound to BAs and their further secretion in bile; secretion in bile of the unchanged Chol [18].

We found that in corvitin-treated rats $(2.5 \mathrm{mg} /$ $\mathrm{kg}$ of flavonoid) the amount of free Chol was not significantly altered in the first, in the second, and in the third half-hour samples. Meanwhile, this index was significantly enhanced in the last hour of the experiment as compared with the control data (Fig. 1).

Corvitin caused a marked increase in the fourth half-hour by $22.8 \%(P<0.05)$, in the fifth - by $24.15 \%(P<0.05)$. At a dose of $5 \mathrm{mg} / \mathrm{kg}$ corvitin, the level of Chol was significantly increased in the third, in the fourth and in the fifth half-hour samples by 62.6\% $(P<0.001), 57.3 \%(P<0.001), 64.8 \%$ $(P<0.001)$, respectively. The output of Chol in response to corvitin treatment at a dose of $10 \mathrm{mg} / \mathrm{kg}$ was higher than in the control rats during the fourth and the fifth half-hour by $40.2 \%(P<0.001)$ and $39.4 \%(P<0.001)$, respectively. Comparison of the Chol level in the bile among the groups showed that the dose of corvitin $5 \mathrm{mg} / \mathrm{kg}$ was most effective in 


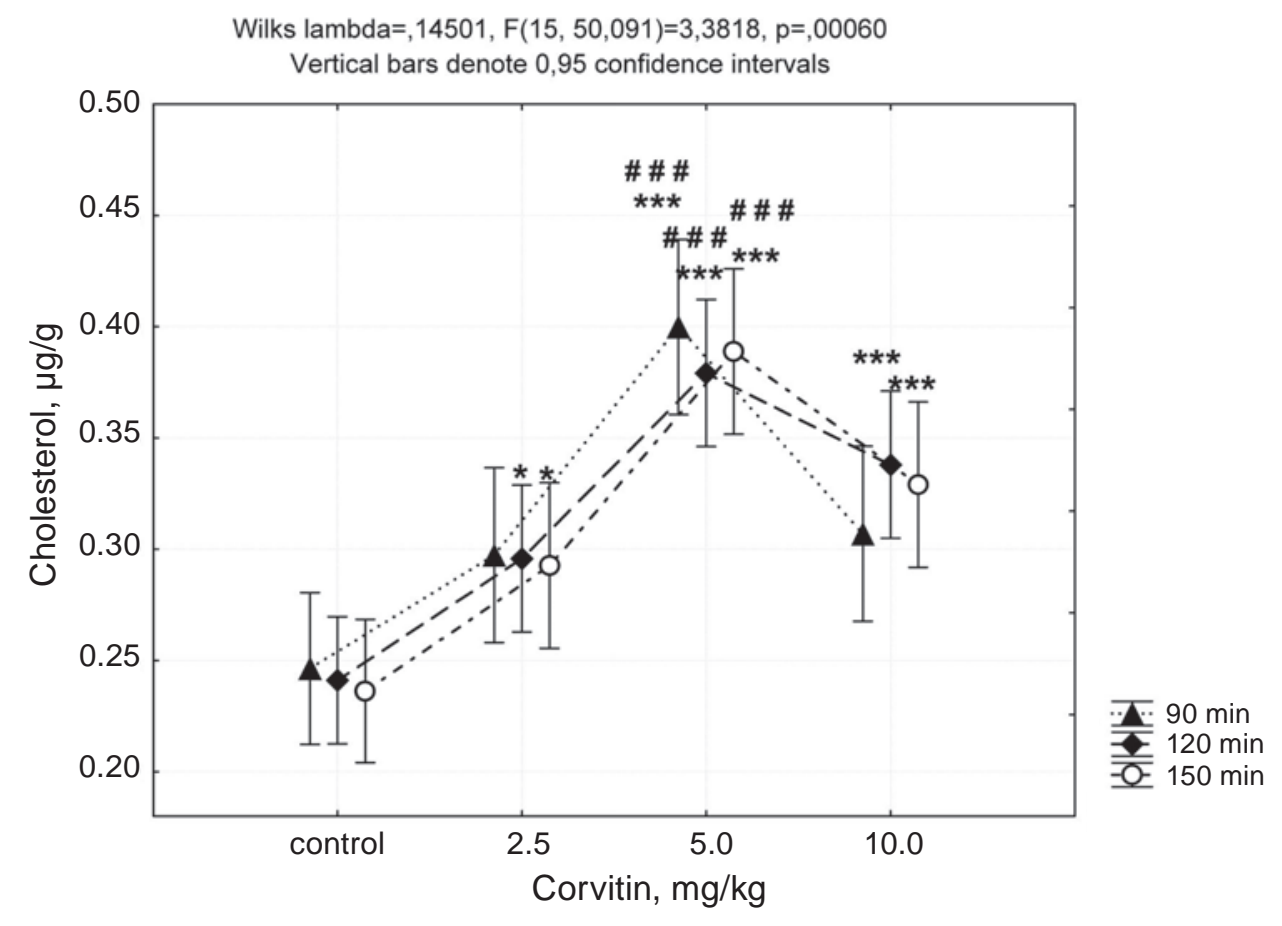

Fig. 1. Changes of the cholesterol level ( $\mu \mathrm{g} / \mathrm{g}$ b.w.) in rat bile under the effect of corvitin $(2.5,5 \mathrm{and} 10 \mathrm{mg} /$ $\mathrm{kg}$ b.w.). Secreted bile was collected every half-hour during the 2.5 hours of the experiment. Means $\pm 95 \mathrm{CI}$; $n=6 ; * P<0.05,{ }^{* * *} P<0.001$ versus control group; ${ }^{*} P<0.001$ corvitin $5 \mathrm{mg} / \mathrm{kg}$ versus corvitin $2.5 \mathrm{mg} / \mathrm{kg}$; observed power (at alpha 0.05) =0.99; partial eta- squared $\left(\eta_{p}{ }^{2}\right)=0.50$

stimulating the excretion of Chol from the liver into bile (Fig. 1). The BAs synthesis provides a direct way of hydrophobic and insoluble Chol conversion into a water-soluble BA molecule, which is easily excreted from the liver into bile immediately after the synthesis, with the bile entering the small intestine where it is reabsorbed and transported back to the liver [19].

In our previous experiments, we observed that corvitin increased the volume of bile and biliary concentration of both total and individual BAs, that is, it enhances the conversion of the Chol to the BAs, accelerating its removal from the body in a liquid crystalline form [15]. Similar results were obtained by other authors in mice [20] and rats [21]. The reason for this effect was that QUE increased both the expression of mRNA and the activity of cholesterol7- $\alpha$-hydroxylase (Cyp7 $\alpha 1$ ) enzyme, which is a key factor in the transformation of Chol into BAs [21]. On the other hand, there is evidence that QUE reduces blood levels of Chol and TGs. Such effect may be due to the increased efficiency of the transport system, which uptakes Chol from the bloodstream and delivers it to hepatocytes [22]. In the present work, we found that QUE increases the secretion of free Chol. The latter is excreted in the intestine in micelles - the temporary structures, which include PLs and BAs along with Chol [23]. Thus, QUE promotes the removal of Chol from the body through the liver involving both main ways. It is important for maintaining homeostasis of Chol in the body. Excessive accumulation of Chol in hepatocytes leads to damage of the liver, as the substance accumulates in the mitochondria, causing their dysfunction, which ultimately leads to complete loss of function of the cells and their death [24]. Bile, besides the free Chol, contains EChols and FFAs, which are a soluble form of Chol removal. We have found that the level of EChols in corvitin-treated rats $(2.5 \mathrm{mg} / \mathrm{kg})$ was not significantly altered in the half-hour samples and increased in the group of rats that received $5 \mathrm{mg} / \mathrm{kg}$ of flavonoid only in the third half-hour sample by $55.2 \%(P<0.05)$. The rats treated with corvitin at a dose of $10 \mathrm{mg} / \mathrm{kg}$ exhibited an increase in biliary EChols efflux in all $2.5 \mathrm{~h}$ of the experiment. The significant increase was observed in the first halfhour by $48.5 \%(P<0.05)$, in the second by $64.3 \%$ $(P<0.01)$, in the third by $51.9 \%(P<0.05)$, in the 
fourth by $47.6 \%(P<0.05)$, and in the fifth by $40 \%$ $(P<0.05)$. So, the most significant increase was observed in the rats treated with corvitin at a dose of $10 \mathrm{mg} / \mathrm{kg}$ (Fig. 2).

The presented data show that corvitin significantly increases the amount of Chol and its esters in 30-min bile samples. In particular, significant changes in the levels of Chol were found in response to all tested doses of flavonoid, but comparison between different experimental groups showed that the maximum level of Chol in the bile was observed at a dose of corvitin $5 \mathrm{mg} / \mathrm{kg}$. On the contrary, the Chol esterification in the liver was activated by corvitin dose of $10 \mathrm{mg} / \mathrm{kg}$, because in this group of rats we found the highest amount of EChols in 30-min samples of bile. Such data are in agreement with the findings of our previous studies, where we have shown that a significant increase in the concentration of Chol and EChols in rat bile occurs under the effect of corvitin at doses of 5 and $10 \mathrm{mg} / \mathrm{kg}$, respectively. In the latter case, there was a decrease in the ratio of $\mathrm{Chol} /$ EChols, which was not observed in other groups
[25]. Increasing EChols excretion into the bile under the effect of corvitin (especially at a dose of $10 \mathrm{mg} /$ $\mathrm{kg}$ ) possibly proves that this flavonoid activates cholesterol-acyl transferase. An enzyme catalyzes the esterification of Chol transforming this highly hydrophobic molecule into a less hydrophobic form. The esterification reaction, catalysed by the rate-limiting enzyme acyl-CoA cholesterol acyltransferase, produces EChols from Chol and fatty acyl coenzyme A. EChols, a neutral lipids stored as droplets in the cell cytosol (the intracellular fluid enclosed by the cell membrane but not held within cellular organelles), allows for a non toxic method of excess cellular Chol storage. In the liver, uptake of Chol leads to an increase in the amount of EChols within the cell that is dependent on the activity of cholesterol-acyl transferase [26]. It should be noted that corvitin had the most significant impact on the production of FFAs, especially when it was used in a dose of $5 \mathrm{mg} / \mathrm{kg}$. In this case, the bile content of FFAs increased almost twice. The secretion of FFAs in bile was enhanced in all three experimental groups of rats compared with

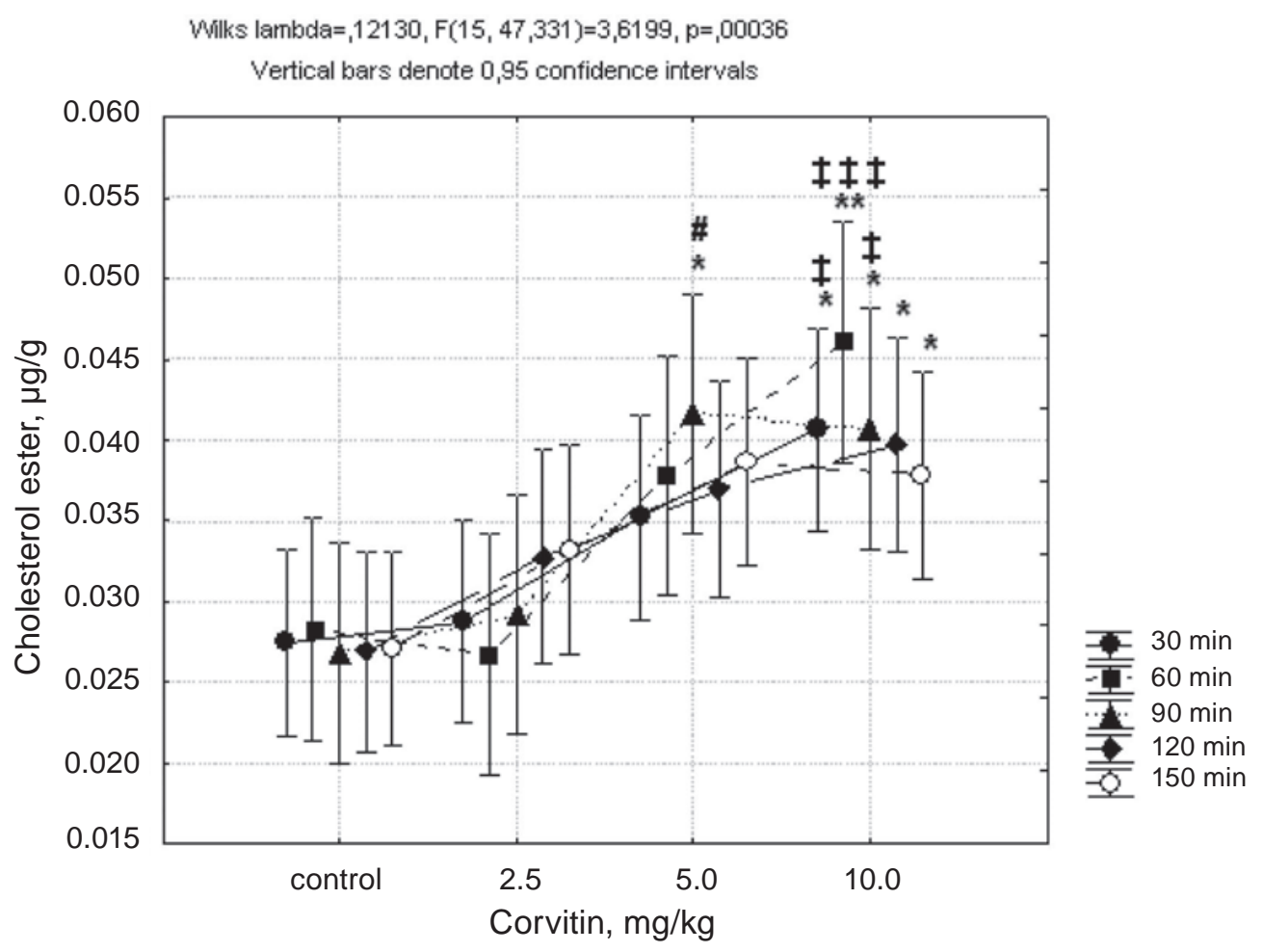

Fig. 2. Changes in the efflux of cholesterol esters ( $\mu \mathrm{g} / \mathrm{g}$ b.w.) in rats bile under the influence of corvitin (2.5, $5,10 \mathrm{mg} / \mathrm{kg}$ ). Secreted bile was collected each half-hour during 2.5 hours of the experiment. Means $\pm 95 \mathrm{CI}$; $n=6 ;{ }^{*} P<0.05,{ }^{* *} P<0.01$ versus control group; ${ }^{\#} P<0.05$ corvitin $5 \mathrm{mg} / \mathrm{kg}$ versus corvitin $2.5 \mathrm{mg} / \mathrm{kg}$; ${ }^{\ddagger} P<0.05,{ }^{\sharp \pm} P<0.001$ corvitin $2.5 \mathrm{mg} / \mathrm{kg}$ versus corvitin $10 \mathrm{mg} / \mathrm{kg}$; observed power (at alpha 0.05) =0.99; partial eta- squared $\left(\eta_{p}^{2}\right)=0.53$ 
the control group. Significant changes were evident from the first half-hour toward the end of the experiment. The most significant increase was observed under the effect of $5 \mathrm{mg} / \mathrm{kg}$ corvitin in the third halfhour by $78.8 \%(P<0.001)$, in the fourth by $79.4 \%$ $(P<0.001)$, in the fifth by $90.3 \%(P<0.001)$ as compared with the results for the control group (Fig 3).

In animals, fatty acids have both an energysupplying and a mechanical function. Some part of the fatty acids that are present in the liver are derivatives of cell membranes, but most of them are synthesized by liver cells de novo. A small amount of these compounds are involved in the secretion of both BAs and Chol into the bile [27]. As the level of esterified Chol increased under the influence of corvitin, we assumed that enhanced synthesis of fatty acids is a preparatory phase for activating the esterification processes in hepatocytes. The latter is necessary for the synthesis of not only EChols but also PLs and TGs.

The level of PLs in all experimental groups in response to corvitin treatment was higher than in the control rats. At the dose of $2.5 \mathrm{mg} / \mathrm{kg}$ corvitin the excretion of PLs into bile increased in the third and in the fourth half-hour sample by $31.15 \%(P<0.05)$ and by $31.2 \%(P<0.05)$, respectively. Rats treated with corvitin at a dose of $5 \mathrm{mg} / \mathrm{kg}$ exhibited an increase in biliary PLs efflux in $2^{\text {nd }}$ to $5^{\text {th }}$ half-hour samples (Fig. 4). The most significant growth of these substances in bile was observed in the third half-hour sample by $55.8 \%(P<0.001)$, and in the fourth by 53.7\% $(P<0.001)$. In our study, corvitin was also used at a dose of $10 \mathrm{mg} / \mathrm{kg}$. As a result, it caused a significant increase in hepatic synthesis of PLs in experimental rats, and the level of bile PLs was markedly incremented in most samples with significant deviations during $2 \mathrm{~h}$ in comparison with control rats. However, the most significant increase was observed in the fourth half-hour by $38.6 \%(P<0.01)$ and in the fifth by $36.1 \%(P<0.01)$ as compared with the results in control rats (Fig. 4). Bile PLs is completely synthesized de novo in the liver. Our results showed that under the influence of corvitin the excretion into the bile both PLs and TGs increased in all experimental groups. The level of bile PLs increased by more than $50 \%$ after the application of corvitin in a dose of $5 \mathrm{mg} / \mathrm{kg}$ (the effect lasted throughout the period of observation). In humans and animals,

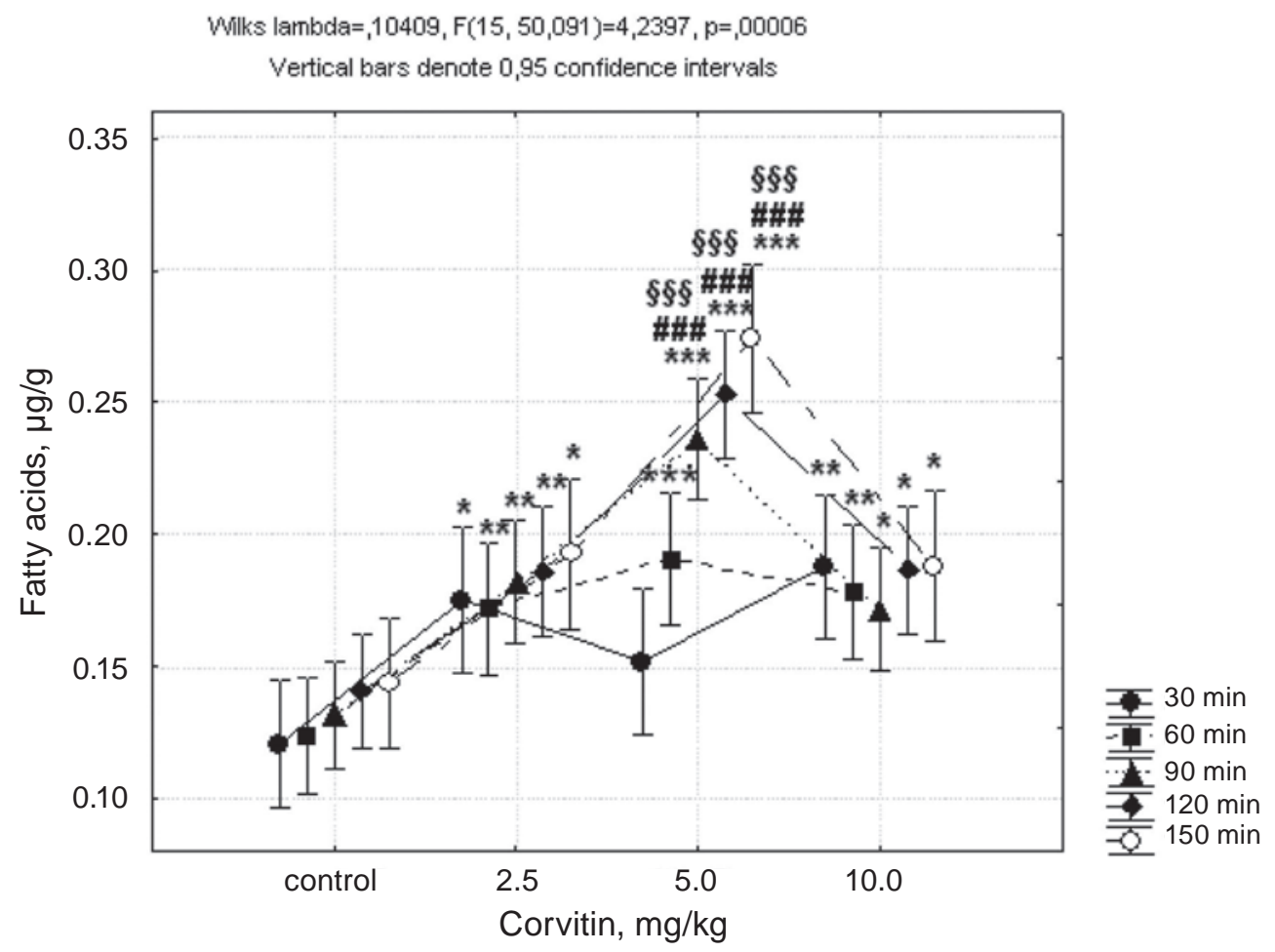

Fig. 3. Effect of corvitin on the level of free fatty acids ( $\mu \mathrm{g} / g$ b.w.) in bile. Secreted bile was collected each half-hour during $2.5 \mathrm{~h}$ of the experiment. Means $\pm 95 \mathrm{CI} ; n=6$; $* P<0.05,{ }^{*} P<0.01$, $* * * P<0.001$ versus control group; ${ }^{\# \# P} P<0.001$ corvitin $5 \mathrm{mg} / \mathrm{kg}$ versus corvitin $2.5 \mathrm{mg} / \mathrm{kg} ;{ }^{\$ \$ \$} P<0.001$ corvitin $5 \mathrm{mg} / \mathrm{kg}$ versus corvitin $10 \mathrm{mg} / \mathrm{kg}$; observed power (at alpha 0.05) $=1.0$; partial eta-squared $\left(\eta_{p}{ }^{2}\right)=0.56$ 


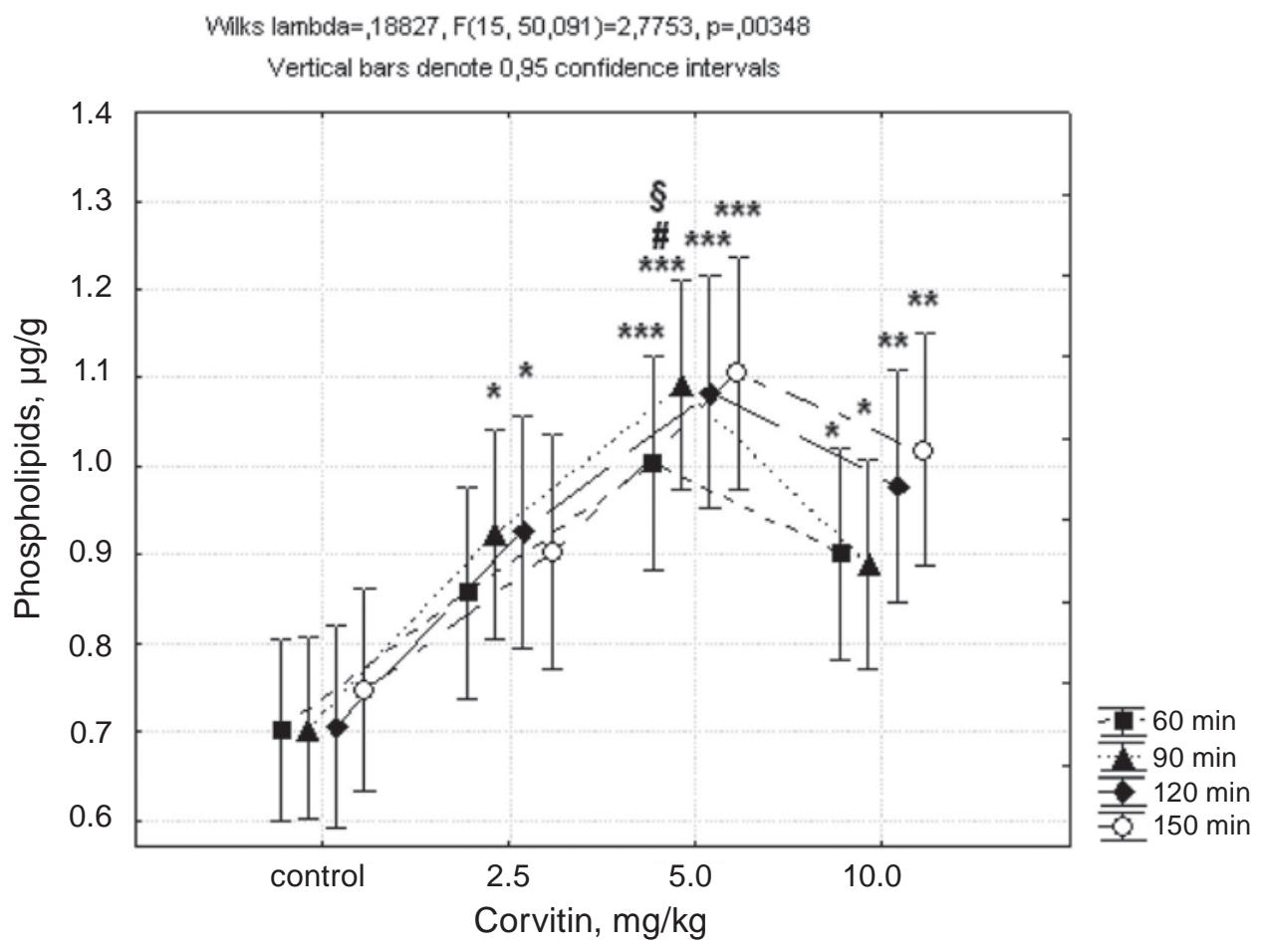

Fig. 4. Changes in the level of the phospholipids in rat bile ( $\mu \mathrm{g} / \mathrm{g}$ b.w.) under the effect of corvitin. Means $\pm 95 C I$; $n=6 ; * P<0.05,{ }^{*} P P<0.01,{ }^{* * *} P<0.001$ as compared with control rats; ${ }^{*} P<0.05$ corvitin $5 \mathrm{mg} / \mathrm{kg}$ versus corvitin $2.5 \mathrm{mg} / \mathrm{kg}$; ${ }^{\S} P<0.05$ corvitin $5 \mathrm{mg} / \mathrm{kg}$ versus corvitin $10 \mathrm{mg} / \mathrm{kg}$; observed power (at alpha 0.05 ) =0.98; partial eta-squared $\left(\eta_{p}^{2}\right)=0.45$

the biological role of PLs is diverse, they are of particular importance for the liver. First of all, PLs are important components of cellular membrane and bile thus their deficiency may cause damage to hepatocytes. In addition, the lack of PLs leads to disorders of bile colloidal stability since they are the basic organic solutes of bile (together with BAs) and play a decisive role in the solubilization of Chol and food lipids. A significant amount of biliary Chol is carried in unilamellar-phospholipid (lecithin) vesicles, in both supersaturated human hepatic bile and unsaturated rat bile. The presence of phosphoric acid residue in the PL molecules makes it a solvent not only for Chol, but also for other hydrophobic compounds. Like BAs, the PL molecules are amphiphilic. The bile PLs, together with BAs and Chol form lamellar or micellar structures. The formation of micelles facilitates dispersion and effective absorption of fats and fat-soluble vitamins in the small intestine. The deficiency of PLs as a critical component for the formation of micelles gradually leads to supersaturation of bile with Chol and the formation of bile concrements [28]. Decreased production of PLs in the liver causes a disturbance in the formation of bile, which is the main mechanism for maintaining lipid homeostasis in the body [29]. In addition, as a result of PLs deficiency, the permeability of the hepatocyte membrane and the accumulation of fat in liver increases because in the absence of PLs, the fatty acids (together with glycerol) form neutral fat that is accumulated in hepatocytes, displacing all other components [30]. Another important role of PLs is that by inhibiting the activity of collagenase, they prevent the synthesis of collagen, which is known to trigger the process of replacing epithelial tissue with the connective tissue [31]. Therefore, we believe that the observed increase in the synthesis of PLs by hepatocytes under the influence of corvitin is a positive factor not only for stabilizing the colloidal system of bile but also for preventing the accumulation of fat in the liver tissue and development of fibrosis.

According to our data, the TGs activity increased under the effect of corvitin, compared with the control value in all experimental groups (Fig. 5).

However, at a drug dose of $2.5 \mathrm{mg} / \mathrm{kg}$, an increase in TGs levels by 35\% $(P<0.05)$ was noted only in the $5^{\text {th }} 30$-min bile assay. The level of TGs in bile increased in samples 2-5 after administration 


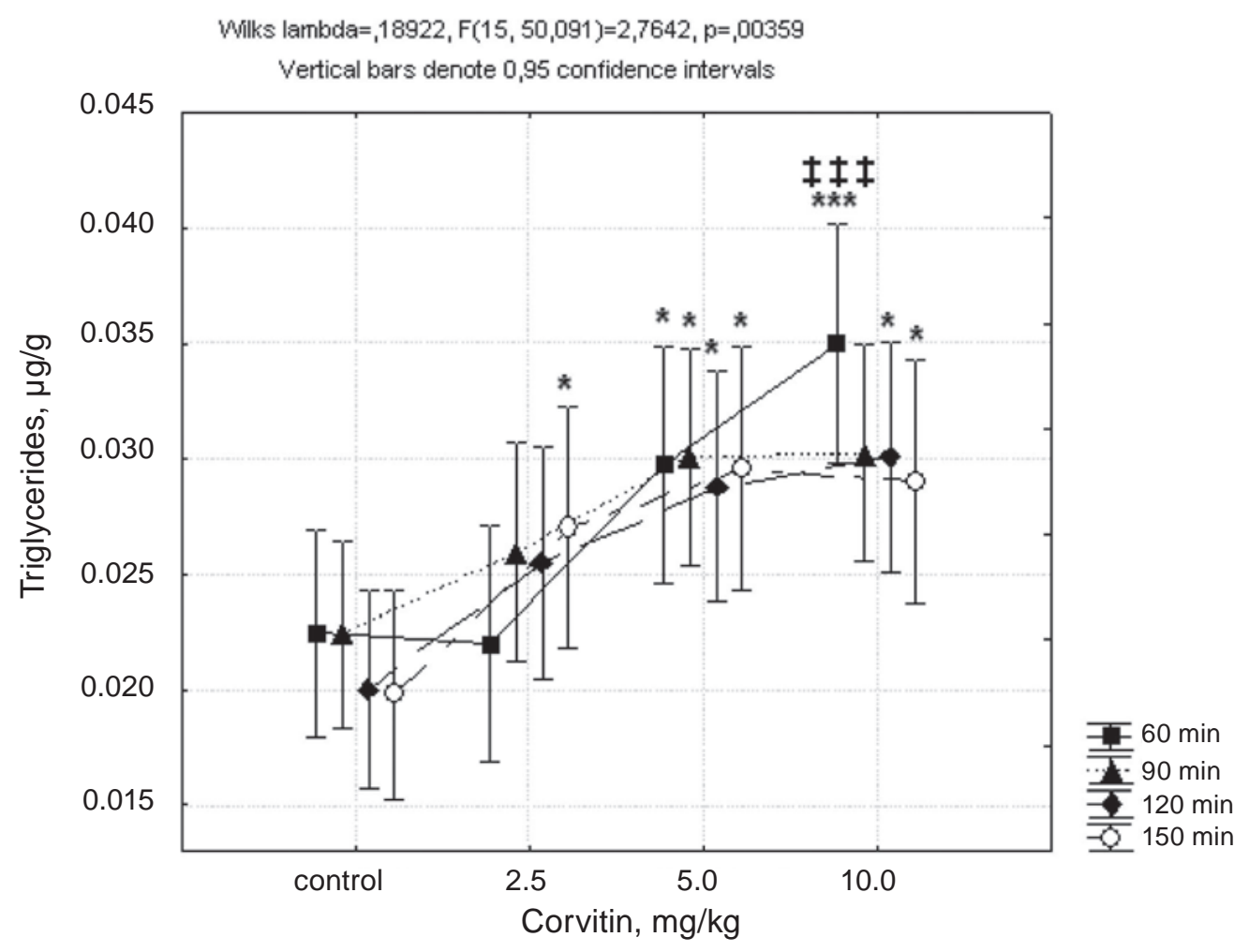

Fig. 5. Changes of triglycerides content $(\mu \mathrm{g} / \mathrm{g}$ b.w.) in rats bile under the effect of corvitin. Bile was collected each half-hour during 2.5 hours of the experiment. Means $\pm 95 C I ; n=6 ; * P<0.05$, ${ }^{* * *} P<0.001$ versus control group; ${ }^{\# P}<0.001$ corvitin $5 \mathrm{mg} / \mathrm{kg}$ versus corvitin $2.5 \mathrm{mg} / \mathrm{kg}$; observed power (at alpha 0.05) $=0.98$; partial eta- squared $\left(\eta_{p}^{2}\right)=0.45$

of $5 \mathrm{mg} / \mathrm{kg}$ corvitin to rats: in the $2^{\text {nd }}$ sample - by 32.6\% $(P<0.05)$, in the $3^{r} \mathrm{~d}-$ by $36.4 \%(P<0.05)$, in the $4^{\text {th }}-$ by $44 \%(P<0.05)$, in the $5^{\text {th }}-$ by $49.9 \%$ $(P<0.05)$. After the application of $10 \mathrm{mg} / \mathrm{kg}$ of the drug, the TGs rate increased, similarly, in the samples $2-5$ by $59.1 \%(\mathrm{P}<0.001)$, in the $3^{\text {rd }}-$ by $36.4 \%$ $(P<0.05)$, in the $4^{\text {th }}-$ by $50 \%(P<0.05)$, in the $5^{\text {th }}-$ by $47.2 \%(P<0.05)$ (Fig. 5). Recent studies provided strong evidence to support the concept that QUE affects the liver lipogenesis, reducing the amount of TGs in the liver tissue and preventing fatty degeneration of the latter in mice. The authors emphasized that this effect depended on the dose of QUE used (larger doses were more effective than small ones) [32]. In the mice fed with a high-fat diet [33], the QUE supplementation reduced liver fat content.

We concluded that corvitin modulates the quantitative composition of lipids in the bile of rats. The drug significantly promoted the excretion of Chol and its esters, PLs, TGs and FFAs from the liver to the bile. In the dose of $5 \mathrm{mg} / \mathrm{kg}$, corvitin most efficiently increased the content of Chol, PLs and FFAs, while $10 \mathrm{mg} / \mathrm{kg}$ of drug activated EChols and TGs synthesis. At a dose of $2.5 \mathrm{mg} / \mathrm{kg}$, corvitin had a moderate effect on the amount of lipids in the bile of rats. Corvitin is suggested to be useful as a monotherapy or in combination with other drugs for the regulation of the synthesis of lipids in the liver and their excretion into bile to improve lipid ratio in bile.

Conflict of interest. Authors have completed the Unified Conflicts of Interest form at http://ukrbiochemjournal.org/wp-content/uploads/2018/12/ coi_disclosure.pdf and declare no conflict of interest. 


\section{КОРВІТИН МОДУЛЮС ВМІСТ ЛІПІДІВ У ЖОВЧІ ЩУ РІВ}

\section{Т. В. Вовкун ${ }^{1}$, П. І. Янчук', Л. Я. Штанова ${ }^{1}$ С. П. Весельський , Н. Б. Філімонова ${ }^{1}$, I. В. Комаров ${ }^{2}$}

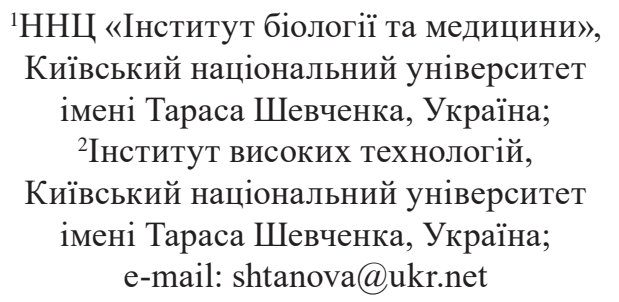

Кверцетин і його розчинна форма корвітин - важливі представники родини флавоноїдів і харчові антиоксиданти 3 найзначною дією. Численні фармакологічні ефекти кверцетину включають захист від таких захворювань, як атеросклероз, інфаркт міокарда та цереброваскулярні патології. Корвітин посилює кровотік у печінці, однак його вплив на зовнішньосекреторну функцію печінки до кінця не вивчено. Ми дослідили ефект корвітину (2,5; 5 і 10 мг/кг) на продукцію ліпідів у печінці щурів, зокрема на рівень у жовчі холестеролу (ХОЛ) і ефірів ХОЛ, фосфоліпідів (ФЛ), вільних жирних кислот (ВЖК) та тригліцеридів (ТГ). Секрет жовчі збирали протягом 2,5 год експерименту. Ліпідні компоненти жовчі розділяли методом тонкошарової хроматографії. Показано, що введення корвітину спричинювало значне $(P<0,05-0,001)$ підвищення рівня всіх досліджуваних ліпідних компонентів жовчі. Корвітин у дозі 2,5 та 5 мг/кг збільшував вміст жовчі щурів у складі ХОЛ, ФЛ та ВЖК, а в дозі 10 мг/кг виявляв найбільший вплив на загальний об'єм ефірів ХОЛ та ТГ. Ми дійшли висновку, що корвітин активізує обмін ліпідів печінки та процеси утворення жовчі.

К л ю ч о в і с ло в а: корвітин, печінка, жовч, холестерол, ефіри холестеролу, фосфоліпіди, вільні жирні кислоти, тригліцериди.

\section{References}

1. Boyer JL. Bile formation and secretion. Compr Physiol. 2013; 3(3): 1035-1078.

2. Farrell GC, Larter CZ. Nonalcoholic fatty liver disease: from steatosis to cirrhosis. Hepatology. 2006; 43(2, Suppl 1): S99-S112.
3. Frishman WH. Frishman WH. Biologic markers as predictors of cardiovascular disease. Am J Med. 1998; 104(6A): 18S-27S.

4. Mendis Sh, Puska P, Norrving B. Global atlas on cardiovascular disease prevention and control. World Health Organization. Geneva: WHO. 2011; VI, 155 p.

5. Fedchyshyn NYe. Analysis of hospital lethality from acute myocardial infarction (according to the date of thw Ternopil University Hospital). Bull Social Hyg Health Prot Organ Ukraine. 2013; (4(58)): 48-51.

6. Hassan HA, El-Gharib NE. Obesity and clinical riskiness relationship: therapeutic management by dietary antioxidant supplementation - a review. Appl Biochem Biotechnol. 2015; 176(3): 647-669.

7. Luca SV, Macovei I, Bujor A, Miron A, Skalicka-Woźniak K, Aprotosoaie AC, Trifan A. Bioactivity of dietary polyphenols: The role of metabolites. Crit Rev Food Sci Nutr. 2019: 1-34.

8. Anand David AV, Arulmoli R, Parasuraman S. Overviews of Biological Importance of Quercetin: A Bioactive Flavonoid. Pharmacogn Rev. 2016; 10(20): 84-89.

9. Son HY, Lee MS, Chang E, Kim SY, Kang B, Ko H, Kim IH, Zhong Q, Jo YH, Kim CT, Kim Y. Formulation and characterization of quercetin-loaded oil in water nanoemulsion and evaluation of hypocholesterolemic activity in rats. Nutrients. 2019; 11(2). pii: E244.

10. Pisonero-Vaquero $\mathrm{S}$, González-Gallego J, Sánchez-Campos S, García-Mediavilla MV. Flavonoids and related compounds in nonalcoholic fatty liver disease therapy. Curr Med Chem. 2015; 22(25): 2991-3012.

11. Miltonprabu S, Tomczyk M, SkalickaWoźniak K, Rastrelli L, Daglia M, Nabavi SF, Alavian SM, Nabavi SM. Hepatoprotective effect of quercetin: From chemistry to medicine. Food Chem Toxicol. 2017; 108(Pt B): 365-374.

12. Parkhomenko ON, Moybenko OO, Kozhukhov SN, Irkin OI, Shklyar LV, Maksyutina NP, Shalamay AS. The first experience of using the intravenous form of inhibitor 5-lipoxygenases in patients with acute myocardial infarction: clinical-hemodynamic parallels, influence on the size of necrosis. Ukr J Cardiol. 2000; 1(2): 5-9. 
13. Vovkun TV, Yanchuk PI, Shtanova LY, Veselsky SP, Baranowskyy VA. Effect of corvitin on secretory processes and blood flow in the rat gastric mucosa. Int $J$ Physiol Pathophysiol. 2013; 4(4): 335-343.

14. Vovkun TV, Yanchuk PI, Shtanova LY, Shalamay AS. Tissue blood flow in the digestive organs of rats with acute pancreatitis after corvitin administration. Fiziol Zh. 2015; 61(6): 53-59. (In Ukrainian).

15. Vovkun TV, Yanchuk PI, Shtanova LY, Veselsky SP, Reshetnik EN, Shalamay AS, Baranowskyy VA. Exocrine function of the liver in rats exposed to corvitin. Int $J$ Physiol Pathophysiol. 2017; 8(3): 207-217.

16. Ghazaee SP, Gorenko ZA, Karbovska LS, Veselsky SP, Yanchuk PI, Makarchuk MY. Desmopressin stimulates bile secretion in anesthetized rats. Gen Physiol Biophys. 2010; 29(2): 151-159.

17. Röhrl C, Stangl H. Cholesterol metabolismphysiological regulation and pathophysiological deregulation by the endoplasmic reticulum. Wien Med Wochenschr. 2018; 168(11-12): 280-285.

18. Cohen DE. Hepatocellular transport and secretion of biliary lipids. Curr Opin Lipidol. 1999; 10(4): 295-302.

19. Russell DW. The enzymes, regulation, and genetics of bile acid synthesis. Annu Rev Biochem. 2003; 72: 137-174.

20. Chavez-Santoscoy RA, Gutierrez-Uribe JA, Granados O, Torre-Villalvazo I, SernaSaldivar SO, Torres N, Palacios-González B, Tovar AR. Flavonoids and saponins extracted from black bean (Phaseolus vulgaris L.) seed coats modulate lipid metabolism and biliary cholesterol secretion in C57BL/6 mice. $\mathrm{Br} J$ Nutr. 2014; 112(6): 886-899.

21. Zhang M, Xie Z, Gao W, Pu L, Wei J, Guo C. Quercetin regulates hepatic cholesterol metabolism by promoting cholesterol-to-bile acid conversion and cholesterol efflux in rats. Nutr Res. 2016; 36(3): 271-279.

22. Padma VV, Lalitha G, Shirony NP, Baskaran R. Effect of quercetin against lindane induced alterations in the serum and hepatic tissue lipids in wistar rats. Asian Pac J Trop Biomed. 2012; 2(11): 910-915.

23. Chan J, Vandeberg JL. Hepatobiliary transport in health and disease. Clin Lipidol. 2012; 7(2): 189-202.

24. Arguello G, Balboa E, Arrese M, Zanlungo S. Recent insights on the role of cholesterol in nonalcoholic fatty liver disease. Biochim Biophys Acta. 2015; 1852(9): 1765-1778.

25. Vovkun T, Yanchuk P, Shtanova L, Veselskiy S, Filimonova N, Shalamay A, Vedmid V. Watersoluble quercetin modulates the choleresis and bile lipid ratio in rats. Gen Physiol Biophys. 2018; 37(1): 111-120.

26. Suckling KE, Stange EF. Role of acyl-CoA: cholesterol acyltransferase in cellular cholesterol metabolism. J Lipid Res. 1985 Jun;26(6):647-71.

27. Mingrone G, Greco AV, Arcieri Mastromattei E. Free fatty acids stimulate mucin hypersecretion by rabbit gall-bladder epithelium in vitro. Clin Sci (Lond). 1990; 78(2): 175-180.

28. Marzolo MP, Rigotti A, Nervi F. Secretion of biliary lipids from the hepatocyte. Hepatology. 1990; 12(3, Pt 2): 134S-141S.

29. Lamont JT, Carey MC. Cholesterol gallstone formation. 2. Pathobiology and pathomechanics. Prog Liver Dis. 1992; 10: 165-191.

30. Rossmeisl M, Medrikova D, van Schothorst EM, Pavlisova J, Kuda O, Hensler M, Bardova K, Flachs P, Stankova B, Vecka M, Tvrzicka E, Zak A, Keijer J, Kopecky J. Omega-3 phospholipids from fish suppress hepatic steatosis by integrated inhibition of biosynthetic pathways in dietary obese mice. Biochim Biophys Acta. 2014; 1841(2): 267-278.

31. Sahebkar A. Fat lowers fat: purified phospholipids as emerging therapies for dyslipidemia. Biochim Biophys Acta. 2013; 1831(4): 887-893.

32. Ying HZ, Liu YH, Yu B, Wang ZY, Zang JN, $\mathrm{Yu} \mathrm{CH}$. Dietary quercetin ameliorates nonalcoholic steatohepatitis induced by a highfat diet in gerbils. Food Chem Toxicol. 2013; 52: 53-60.

33. Jung CH, Cho I, Ahn J, Jeon TI, Ha TY. Quercetin reduces high-fat diet-induced fat accumulation in the liver by regulating lipid metabolism genes. Phytother Res. 2013; 27(1): 139-143. 